\title{
SULUH
}

JURNAL BIMBINGAN DAN KONSELING

http://journal.umpalangkaraya.ac.id/index.php/suluh

\section{MENINGKATKAN KEPERCAYAAN DIRI SISWA MENGGUNAKAN BIMBINGAN KELOIMPOK DENGAN TEKNIK SOSIODRAMA PESERTA DIDIK SMIA N 4 PALANGKA RAYA}

\author{
Improving Self-Confidence Of Students Using Group Bimbing With \\ Participants Of Sociodrama Techniques In Sma N 4 Palangka Raya
}

'Esthi Puspitarini, ${ }^{2}$ M. Fatchurahman

IUniversitas Muhammadiyah Palangkaraya, Jekan Raya, Palangka Raya, Kalimantan Tengah, Indonesia

2 Universitas Muhammadiyah Palangkaraya, Jekan Raya, Palangka Raya, Kalimantan Tengah, Indonesia

\section{ARTIKEL INFO}

\section{Diterima}

Juni 2017

Dipublikasi

Agustus 2017

*E-mail:

dinafarizats@gmail.com

\begin{abstract}
Tujuan penelitian ini untuk mengetahui apakah bimbingan kelompok dengan teknik sosiodrama dapat meningkatkan kepercayaan diri peserta didik. Metodologi penelitianyang dipakai yaitu experiment. Populasi dalam penelitian ini yaitu peserta didik SMA negeri 4 plangkaraya. Terdapat peningkatan kepercayaan diri siswa sesudah pre-test dan post-test artinya "Bimbingan Kelompok Teknik Sosiodrama Untuk meningkatkan kepercayaan diri siswa di SMA N-4 Palangka Raya".menunjukan bahwa kelompok eksperimen mengalami kenaikan skor dari sebelum mendapatkan intervensi pre-tes dan setelah mendapatkan intervensi berupa post-test. Hasil uji pre-tes dan post-tes dapat dihitung diperoleh informasi bahwa nilai Asymp. Sig. (2-tailed) adalah 2,539. Karena nilai Asymp. Sig. $<$ taraf nyata $(\alpha / 2=0, \mathrm{II})$ maka $\mathrm{Ho}$ ditolak dan $\mathrm{Ha}$ diterima. Hal itu berarti ada peningkatan kepercayaan diri siswa sesudah pre-test dan post-test artinya Hasil analisis menunjukkan bahwa peserta didik pada kelompok eksperimen mengalami kenaikan skor dari sebelum mendapatkan intervensi pre-tes $43 \%$ dan setelah mendapatkan intervensi berupa post-test $70 \%$, sehingga diketahui bahwa teknik sosiodrama dapat meningkatkan kepercayaan diri siswa SMA N - 4 Palangka Raya
\end{abstract}

ABSTRAK

Kata kunci: percaya diri, bimbingan kelompok, teknik sosiodrama

\begin{abstract}
The purpose of this study was to determine whether group counseling with sociodrama techniques could improve students' self-confidence. The research methodology used is the experiment. The population in this study was 4 plangkaraya public high school students. There is an increase in students 'self-confidence after the pre-test and post-test means "Guidance for Sociodrama Techniques To increase students' self-confidence in Palangka Raya N-4 High School". intervention in the form of a post-test. The results of the pre-test and post-test test can be calculated to obtain information that the value of Asymp. Sig. (2tailed) is 2.539. Because the value of Asymp. Sig. < real level $(\alpha / 2=0.1 \mathrm{I})$ then $\mathrm{Ho}$ is rejected and $\mathrm{Ha}$ is accepted. That means there is an increase in students' self-confidence after the pre-test and post-test. The analysis shows that students in the experimental group experienced an increase in scores from before getting a pre-test intervention $43 \%$ and after getting an intervention in the form of a $70 \%$ post-test, so It is known that sociodrama techniques can increase the confidence of Palangka Raya N-4 High School students
\end{abstract}

Keywords: confidence, group guidance, sociodrama techniques 
Jurnal Bimbingan dan Konseling

\section{PENDAHULUAN}

Menurut Rosita (2012:18) Rasa kurang percaya diri di lingkungan masyarakat sekarang saat ini sungguh mengkhawatirkan berkenaan dengan lingkungan yang kurang adanya rasa kasih sayang, kurangnya dukungan orang tua serta tidak adanya hubungan komunikasi yang baik antar sesama, Terutama pada masa SMA kurangnya rasa percaya diri ini sering terjadi.

Menurut Angelis (Suhardita, 20II:I3I), dalam mengembangkan percaya diri terdapat tiga aspek yaitu: I) Tingkah laku, yang memiliki tiga indikator; melakukan sesuatu secara maksimal, mendapat bantuan dari orang lain, dan mampu menghadapi segala kendala, 2)Emosi, terdiri dari empat indikator; memahami perasaan sendiri, mengungkapkan perasaan sendiri, memperoleh kasih sayang, dan perhatian disaat mengalami kesulitan, memahami manfaat apa yang dapat disumbangkan kepada orang lain, dan 3) Spiritual, terdiri dari tiga indikator; memahami bahwa alam semesta adalah sebuah misteri, meyakini takdir Tuhan, dan mengagungkan Tuhan.

Siswa Sekolah Menengah Atas (SMA) berada pada fase remaja akhir. Menurut Aristoteles (Yusuf 2012:20) menggambarkan perkembangan individu, sejak anak sampai dewasa itu kedalam tiga tahapan. Siswa SMA berada pada tahap ketiga yaitu dari I4,0 sampai 2I,0 tahun (masa remaja / pubertas, masa peralihan dari usia anak menjadi orang dewasa).

Menurut Yusuf (2012:26) masa usia sekolah menengah masa remaja akhir setelah remaja dapat menentukan pendirian hidupnya, pada dasarnya telah tercapailah masa remaja akhir dan telah terpenuhilah tugas-tugas perkembangan masa remaja, yaitu menemukan pendirian hidup dan masuklah individu ke dalam masa dewasa.

Berdasarkan hasil observasi di lingkungan sekolah SMA Negeri 4 Palangka
Raya pada hari senin, tanggal I4 Maret 2016, terdapat siswa yang kurang percaya diri, siswa jarang berkomunikasi dengan temannya (diam saja), siswa sering menyendiri (duduk sendirian di kelas pada jam istirahat), siswa tidak mau bertanya kepada guru jika ia tidak mengerti dalam mata pelajaran yang sedang berlangsung (sisiwa diam saja saat di tanya guru tidak menjawab). Serta terdapat siswa yang Menutup diri (siswa tidak mau bergaul dengan teman-teman sekelasnya), padahal manusia merupakan makhluk sosial, artinya ia membutuhkan hubungan dengan manusia lain untuk mencukupi kebutuhan hidupnya. Seseorang yang mengalami suatu permasalahan yang memberatkan diri memerlukan temen berbagi untuk memotivasi dan membantunya meringankan beban yang dialaminya sehingga ia merasa lega dan percaya diri.

Untuk memperoleh kejelasan mengenai keadaan siswa yang ingin diteliti, maka dilakukan wawancara dengan guru BK di SMA Negeri 4 Palangka Raya. Hasil wawancara dengan guru BK di sekolah sebagai berikut: Wawancara dilakukan di SMA Negeri 4 Palangka Raya pada hari senin tanggal 2l Maret 2016. Hasil dari wawancara dengan bapak Edy guru BK di SMA Negeri 4 Palangka Raya terutama di kelas $X$ ini ada delapan orang siswa yang mempunyai kurang percaya diri, sering menyendiri, tidak mau bertanya kepada guru jika ia tidak mengerti dalam mata pelajaran yang sedang berlangsung, Menutup diri.Berdasarkan Fenomena tersebut di atas, maka peneliti tertarik untuk melaksanakan penelitian tentang bagaimana upaya meningkatkan kepercayaan diri siswa dengan menggunakan teknik sosiodrama. Sehingga penulis mengadakan penelitian dengan judul: “ Meningkatkan kepercayaan diri siswa menggunakan bimbingan kelompok dengan teknik sosiodrama pada peserta didik SMA Negeri 4 Palangka Raya". 


\section{METODOLOGI PENELITIAN}

Penelitian ini menggunkan pendekatan eksperimen. Menurut Sanjaya (2013) "Eksperimen adalah metode penelitian yang bertujuan untuk menjelaskan dan meramalkan yang akan terjadi pada suatu variabel manakala diberikan suatu perlakuan tertentu pada variabel lainnya". Menurut Arikunto (2013: 3) "adalah suatu cara untuk mencari sebab akibat (hubungan kausal) antara dua faktor yang sengaja ditimbulkan oleh peneliti dengan mengurangi atau menyisihkan faktor-faktor lain yang bisa mengganggu". Pendektan experiment yang digunakan dalam penelitian ini yaitu digunakan guasi experiment yang memiliki kelompok control dalam penelitiannya.

\section{HASIL DAN PEMBAHASAN}

Parameter uji: Jika $t$ tabel $\geq \mathrm{t}$ hitung maka $\mathrm{H} 0$ diterima, dan $\mathrm{Ha}$ di tolak Jika $\mathrm{t}$ tabel $<\mathrm{t}$ hitung maka $\mathrm{HO}$ ditolak, dan $\mathrm{Ha}$ diterima hasil uji pre-tes dan post-tes dapat dihitung diperoleh informasi bahwa nilai Asymp. Sig. (2tailed) adalah 2,539. Karena nilai Asymp. Sig. < taraf nyata $(\alpha / 2=0, \mathrm{I}$ I) maka Ho ditolak dan $\mathrm{Ha}$ diterima. Hal itu berarti ada peningkatan kepercayaan diri siswa sesudah pre-test dan post-test artinya "Bimbingan Kelompok Teknik Sosiodrama Untuk meningkatkan kepercayaan diri siswa di SMA N-4 Palangka Raya". Menunjukan bahwa kelompok eksperimen mengalami kenaikan skor dari sebelum mendapatkan ntervensi pre-tes dan setelah mendapatkan intervensi berupa post-test.

Perhitungan hipotesis menggunakan bantuan SPSS 21.00. Hasil perhitungan menggunakan bantuan aplikasi SPSS 21.00 Karena Ha: Adanya peningkatan kepercayaan diri bimbingan kelompok dengan teknik sosiodrama terhadap meningkatkan kepercayaan diri siswa di SMA N - 4 Palangka Raya. H0: Tidak ada peningkatan kepercayaan diri bimbingan kelompok dengan teknik sosiodrama terhadap meningkatkan kepercayaan diri siswa di SMA N-4 Palangka Raya

\section{KESIMPULAN}

Berdasarkan hasil analisis dan pembahasan, maka dapat diketahui bahwa pada hasil uji pre-tes dan post-tes dapat dihitung diperoleh informasi bahwa nilai Asymp. Sig. (2-tailed) adalah 2,539. Karena nilai Asymp. Sig. $<$ taraf nyata $(\alpha / 2=0, \mathrm{II})$ maka Ho ditolak dan $\mathrm{Ha}$ diterima. Hal itu berarti ada peningkatan kepercayaan diri siswa sesudah pre-test dan post-test artinya Hasil analisis menunjukkan bahwa peserta didik pada kelompok eksperimen mengalami kenaikan skor dari sebelum mendapatkan intervensi pre-tes $43 \%$ dan setelah mendapatkan intervensi berupa post-test $70 \%$, sehingga diketahui bahwa teknik sosiodrama dapat meningkatkan kepercayaan diri siswa SMA N - 4 Palangka Raya.

\section{DAFTAR PUSTAKA}

Kalteng pos. 20I5. Jumlah Pengguna Internet $\mathrm{Di}$ Indonesia.

http://kaltengpos.web.id/berita/detail//6938/ju mlah-pengguna-internetdi-indonesia terbesar-di-dunia.Diunduh pada hari senin tanggal 5 April 2015 pukul 16.35 WIB.

Lesmana, Aditya. 2012. Analisis pengaruh media sosial tweeter terhadap pembentukan Band attachment. Universitas Indonesia:Jakarta.

Mujib, Muhammad. 2013. Pengaruh penggunaan internet terhadap hasil belajar peserta didik SMA di kota Yogyakarta. Universitas islam negeri sunan kalijaga. Yogyakarta.

Purnama, Hadi. 201I. Media sosial diera pemasaran. Corporate Ana marketing Communications.Jakarta 